\title{
Advanced glycation end products increase lipids accumulation in macrophages through upregulation of receptor of advanced glycation end products: increasing uptake, esterification and decreasing efflux of cholesterol
}

Lei $X u^{1}$, Yi-Ru Wang ${ }^{2}$, Pei-Cheng $L^{2} i^{2}$ and Bo Feng ${ }^{1,3^{*}}$

\begin{abstract}
Background: Previous reports have suggested that advanced glycation end products (AGEs) participate in the pathogenesis of diabetic macroangiopathy. Our previous study have found that AGEs can increase the lipid droplets accumulation in aortas of diabetic rats, but the current understanding of the mechanisms remains incomplete by which AGEs affect lipids accumulation in macrophages and accelerate atherosclerosis. In this study, we investigated the role of AGEs on lipids accumulation in macrophages and the possible molecular mechanisms including cholesterol influx, esterification and efflux of macrophages.

Methods: THP-1 cells were incubated with PMA to differentiate to be macrophages which were treated with AGEs in the concentration of $300 \mu \mathrm{g} / \mathrm{ml}$ and $600 \mu \mathrm{g} / \mathrm{ml}$ with or without anti-RAGE (receptor for AGEs) antibody and then stimulated by oxidized-LDL (oxLDL) or Dil-oxLDL. Lipids accumulation was examined by oil red staining. The cholesterol uptake, esterification and efflux were detected respectively by fluorescence microscope, enzymatic assay kit and fluorescence microplate. Quantitative RT-PCR and Western blot were used to measure expression of the moleculars involved in cholesterol uptake, synthesis/esterification and efflux.

Results: AGEs increased lipids accumulation in macrophages in a concentration-dependent manner. $600 \mu \mathrm{g} / \mathrm{ml}$ AGEs obviously upregulated oxLDL uptake, increased levels of cholesterol ester in macrophages, and decreased the HDL-mediated cholesterol efflux by regulating the main molecular expression including CD36, Scavenger receptors (SR) A2, HMG-CoA reductase (HMGCR), ACAT1 and ATP-binding cassette transporter G1 (ABCG1). The changes above were inversed when the cells were pretreated with anti-RAGE antibody.

Conclusions: The current study suggest that AGEs can increase lipids accumulation in macrophages by regulating cholesterol uptake, esterification and efflux mainly through binding with RAGE, which provide a deep understanding of mechanisms how AGEs accelerating diabetic atherogenesis.
\end{abstract}

Keywords: AGEs, RAGE, Macrophages, Diabetes, Atherosclerosis, Cholesterol

\footnotetext{
*Correspondence: fengbo201607@126.com

'Department of Endocriology and Metabolic Disease, East Hospital, Tongji

University School of Medicine, Shanghai 200120, China

${ }^{3}$ Ji-mo Road 150, Shanghai 200120, China

Full list of author information is available at the end of the article
} 


\section{Background}

It is well established that people with diabetes mellitus have a greater risk of cardiovascular morbidity and mortality than their normal counterparts. More than $50 \%$ of diabetes-related deaths are associated with macrovascular complications, especially atherosclerosis [1]. Multiple risk factors are associated with atherosclerosis, including hyperglycemia, hyperlipidemia, and dysregulation of the angiotensin system $[2,3]$. Recent studies show that oxidative stress and advanced glycation also play an important role in the development of diabetic macrovascular disease $[4,5]$. Advanced glycation end products (AGEs), a heterogeneous group of complex structures, form nonenzymatically when reducing sugars react with free amino groups on proteins, lipids, or nucleic acids. AGEs formation and accumulation, processes of normal aging driven by hyperglycemia, occur at an accelerated rate in diabetic patients and may participate in the pathogenesis of diabetic vascular disease [6]. The interaction between AGEs and its receptor, RAGE, contributes to the progression of atherosclerosis and accelerates oxidative stress [7-10]. RAGE, a member of the immunoglobulin superfamily of cell surface molecules, is a multi-ligand receptor on vascular cells that plays a key role in inflammatory processes [11]. Unlike other receptors that are downregulated by increased levels of their ligands, the RAGE-ligand interaction leads to positive feedback activation which further increases receptor expression [12]. There is increasing evidence that in diabetic patients, activation of the AGEs-RAGE pathway plays a central role in the cascade of events that result in accelerated atherosclerotic plaque formation, plaque erosion and fissuring $[13,14]$.

Atherosclerosis is a chronic disease characterized by the deposition of excessive cholesterol in the arterial intima. Macrophage foam cells play a critical role in the occurrence and development of atherosclerosis. Macrophage cholesterol homeostasis maintenance is the result of a balance among influx, endogenous synthesis, catabolism, and efflux [15]. Scavenger receptors (SRs), CD36 and SR class A (SR-A) are the principal receptors responsible for the binding and uptake of ox-LDL in macrophages [16]. ACAT1 and neutral cholesteryl ester hydrolase (nCEH) play a critical role in cholesterol esterification [17]. ATP-binding cassette (ABC) transporter A1(ABCA1), ABCG1 and SR-BI mediate cholesterol export from macrophages [18]. Expressions of ABCA1, ABCG1 and apoE are mediated through the nuclear receptors, liver $\mathrm{X}$ receptor (LXR) $\alpha$ and PPAR $\gamma$ [19]. Besides that, HMG-CoA reductase (HMGCR), a rate-limiting enzyme for cholesterol synthesis, can also exerts its regulation effect on cholesterol synthesis at the transcriptional level [20]. It is related with the free cholesterol (FC) level of macrophage $[21,22]$. When inflow and esterification of cholesterol increase and/or its outflow decrease, excessive esterified cholesterol (CE) will accumulate as lipid droplets in macrophages, thereby contributing to the formation of foam cells which initiate atherosclerosis.

Our previous study has found that AGEs-RAGE axis can increase the lipid droplets accumulation in the aortas of diabetic rats [23]. In that study, we observed obvious lipid droplets in the cytoplasm of smooth muscle cells and basal membrane of aortas when there were not any classical pathological changes of atherosclerosis can be seen by HE stainning in high-diet fed diabetic Goto Kakisaki (GK) rats. The expression of RAGE was also increased in aortas of GK rats. Recent experimental evidence also suggests that AGEs may promote foam cells formation [24-26]. However, the roles of AGEs in influencing the uptake, synthesis and efflux of cholesterol in macrophages and the underlying mechanisms are poorly understood. In the present study, we intended to investigate the effect of AGEs on lipid accumulation in macrophages stimulated with oxidized-LDL (oxLDL). Furthermore, we investigated the effects of AGEs-RAGE interaction on regulating cellular cholesterol efflux, influx, and esterification in THP-1 macrophages. This study will provide a new strategy for the treatment of diabetic atherosclerosis.

\section{Methods}

\section{Preparation of model AGEs}

BSA and D-glucose (Sigma, USA) were dissolved in phosphate-buffered saline PBS ( $\mathrm{pH} 7.2-7.4$ ), and the final concentrations of BSA and D-glucose was $5 \mathrm{~g} / \mathrm{L}$ and $50 \mathrm{mmol} / \mathrm{L}$, respectively. EDTA was added to a final concentration of $0.5 \mathrm{mmol} / \mathrm{L}$ to reduce oxidation. Penicillin (100 U/L) and streptomycin $(100 \mu \mathrm{g} / \mathrm{ml})$ were added to the reaction mixture to prevent bacterial contamination. The reaction mixture was filtered through $0.22 \mu \mathrm{m}$ filter and then incubated in electrothermal incubation at $37{ }^{\circ} \mathrm{C}$ for 12 weeks. At the end of the incubation period, the reaction mixture was dialyzed against sterilized PBS ( $\mathrm{pH} 7.2-7.4)$ to remove the unconjugated glucose; the glucose in the dialyzate was $<0.03 \mathrm{mmol} / \mathrm{L}$. The reaction mixture was measured in a fluorospectrophotometer with an excitation wave of $370 \mathrm{~nm}$, and the maximum absorption peak was measured at $440 \mathrm{~nm}$ to verify that the mixture was AGE-BSA. Finally, the AGE-BSA was freeze-dried and stored at $4{ }^{\circ} \mathrm{C}$.

\section{Cell culture and treatment}

Human monocytic cell line THP-1 was purchased from Scientific Research Institute, Shanghai, China and cultured in RPMI 1640 medium containing $10 \%$ FBS, $10 \mathrm{mM}$ HEPES (Sigma, USA), and $1 \%$ pen/strep solution at a density of $5 \times 10^{5}$ cells $/ \mathrm{ml}$ in a $5 \% \mathrm{CO} 2$ incubator. The cells were seeded in six-well plates for $48 \mathrm{~h}$ in the presence of $100 \mathrm{ng} / \mathrm{ml} \mathrm{PMA,} \mathrm{(Sigma,} \mathrm{USA)} \mathrm{which} \mathrm{allowed}$ 
them to differentiate into adherent macrophages. The culture medium was then changed into RPMI1640 medium containing $0.1 \%$ FBS for $6 \mathrm{~h}$ of cell starvation. The macrophages were pretreated with BSA $(600 \mu \mathrm{g} / \mathrm{ml})$ as control group or with different concentration of AGEs $(300 \mu \mathrm{g} / \mathrm{ml}$ and $600 \mu \mathrm{g} / \mathrm{ml})$ for $2 \mathrm{~h}$, then stimulated with oxLDL $(100 \mu \mathrm{g} / \mathrm{ml})$ (Jingke Chemistry, China) for $24 \mathrm{~h}$ at $4{ }^{\circ} \mathrm{C}$ in a $5 \% \mathrm{CO} 2$ incubator, and then collected for detection. To observe the effect of RAGE, one group of cells was treated with anti-RAGE antibody $(10 \mu \mathrm{g} / \mathrm{ml})($ Abcam, USA) for $2 \mathrm{~h}$ before adding high concentration of AGEs $(600 \mu \mathrm{g} / \mathrm{ml})$.

\section{Oil red $\mathrm{O}$ staining}

After the above mentioned treatment, the cells were collected, washed twice with ice-cold PBS, and then fixed with $10 \%$ neutral-buffered formalin for $15 \mathrm{~min}$. The cells were washed again with $60 \%$ isopropyl alcohol for $1 \mathrm{~min}$ and then stained with oil red O (Sigma, USA) for $15 \mathrm{~min}$. The oil red $\mathrm{O}$ was discarded, and excess dye was washed away with $60 \%$ isopropyl alcohol. After washing with distilled water, the specimens of each group were placed under an inverted microscope to observe oil red staining. Cellular lipid accumulation was quantified by the optical density(OD) at $518 \mathrm{~nm}$ of Oil Red O extracted from stained cells using isopropanol. The results were normalized as OD value/number of cells.

\section{RNA isolation and quantitative RT-PCR}

Total RNA was isolated using Trizol reagent (Invitrogen, CA). For reverse transcription, $2 \mu \mathrm{g}$ of the total RNA was converted to first strand complementary DNA in $20 \mu \mathrm{l}$ reactions using a reverse transcription kit (Thermo, USA). Quantitative real-time PCR analysis was performed (StepOne, Applied Biosystems) using SYBR Green (Takara, JAP). The thermal cycling program was $10 \mathrm{~min}$ at $95{ }^{\circ} \mathrm{C}$ for enzyme activation and 40 cycles of denaturation for $15 \mathrm{~s}$ at $95^{\circ} \mathrm{C}, 5 \mathrm{~min}$ at $60^{\circ} \mathrm{C}$ for annealing and extension. The comparative cycle threshold (CT) method was used to determine relative mRNA expression of genes as normalized by GAPDH housekeeping gene. Gene expression was determined by the $2^{-\Delta \Delta C t}$ method. Primers used were as follows: 5'-GAAACTGAACACA GGCCGGA-3' for RAGE-F, 5' - CACGGACTCGGTAG TTGGAC-3' for RAGE - R; 5' - TAAGATCAGGTGGG TTGGGC -3' for SRA2-F; 5' -CAGGTACAACACGG GAACCA -3' for SRA2-R; 5' -TCCTCTGGCAACA AACCACA-3' for CD36-F; 5' -AAGTCCTACACT GC AGTCCTC -3' for CD36-R; 5' -TGTCTGATGGCCG CTTTCT -3' for ABCG1-F; 5' -CACCTCATCCACCG AGACAC -3' for ABCG1-R; 5' -AGGGAGAG CACA GGCTTTGAC -3' for ABCA1-F; 5' -CCCCACTCAC TCTCGCTCG -3' for ABCA1-R; 5' -TCTTATTGGTC GAAGGCTCGT -3' for HMGCR-F; 5' -TCTCACT
AGAGGCCACCGAA -3' for HMGCR-R; 5' -AGCC AAGGTACAGGTAACGA -3' for LXR $\alpha-F ; 5^{\prime}$-GATTA CAACGGTGATGGCGG -3' for - LXR $\alpha R$; 5' -TAG TCTACGCCTGTGGAGCC -3' for ACAT-1-F; 5' -TC TTATTTCCTG CACCAGCCTC -3' for - ACAT-1 - R; 5' -GTAAACACGCTCCTCTAA -3' for GAPDH-F; 5' -TGACGGGATCTCGCTCCTGGAAGAT -3' for GAPDH- R.

\section{Protein isolation and Western blot analysis}

After treatment of cells as indicated above, cells were lysed with RIPA lysis buffer $(50 \mathrm{mmol} / \mathrm{L}$ Tris $\mathrm{pH} 7.5$, $150 \mathrm{mmol} / \mathrm{L} \mathrm{NaCl}, 1 \mathrm{mmol} / \mathrm{L}$ EDTA, 1 \% Triton X-100, $1 \%$ sodium deoxycholate, $0.1 \%$ SDS) containing protease inhibitor cocktail (Sigma, USA), and protein concentrations of lysates determined by the BCA assay kit (Beyotime, China). Proteins (20 $\mu \mathrm{g}$ of extracts) were electrophoresed by $12 \%$ SDS-PAGE, and transferred to a nitrocellulose membrane. The membranes were blocked overnight at $4{ }^{\circ} \mathrm{C}$ in $5 \%$ skim milk, and then incubated with primary antibodies against for RAGE, SRA2, CD36, ABCA1, ABCG1, LXR $\alpha$, HMGCR and ACAT1 (1:1000), (Abcam, USA) $2 \mathrm{~h}$ at room temperature. The membranes were washed with TBS-T, and incubated with a horseradish peroxidase conjugated secondary anti-mouse or anti-rabbit IgG antibody (1:5000, Bioss, China) for $1 \mathrm{~h}$ at $37^{\circ} \mathrm{C}$. Afterwards blots were developed using ECL Plus. The signal intensities of specific bands were detected with a Clinx ChemiScope imaging-system (Qinxiang, China) and quantified using TotalLab TL100-Quick Start analysis software.

\section{Measurement of intracellular cholesterol and cholesterol esterification}

After treatment of cells as indicated above, cells were washed twice with PBS, cellular lipids extracted with a mixture of hexane and isopropanol $(3: 2 \mathrm{v} / \mathrm{v})$, and lipid extracts dried under a stream of nitrogen. Total cholesterol (TC) and FC concentrations were determined using enzymatic assay kit (Applygene Technologies Inc, China) in accordance with the manufacturer's instructions. The concentration of $\mathrm{CE}$ was determined by subtraction of the concentration of free cholesterol from that of total cholesterol. Cholesterol concentrations were related to cellular protein as determined by the BCA protein assay kit (Beyotime, China). Cellular protein was obtained by lysis of cells in $0.2 \mathrm{~mol} / \mathrm{L} \mathrm{NaOH}$ after extraction of cellular lipids. Results are expressed as lipids/mg cellular protein.

\section{Cholesterol uptake assay}

The treated macrophages were incubated with 1,1'dioctadecyl- 3,3,3,3' -tetramethylin docarbocyaninet (Dil)oxLDL $(40 \mu \mathrm{g} / \mathrm{ml})$ (Jingke Chemistry, China) instead of oxLDL for $24 \mathrm{~h}$. After the medium was removed, cells 
were washed twice with PBS. The specimens of each group were placed under an inverted fluorescence microscope (OLYMPUS, CKX41, JAP). Fluorescence intensity was expressed as Mean fluorescence intensity (MFI)/ number of cells, and MFI was caculated by the cumulative fluorescence density/area analysed by Image-Pro Plus 6.0. Fluorescent intensity was quantified from at least 3 random fields $(1024 \times 1024$ pixels $)$ per slide, from 3 slides per experimental condition and graphed.

\section{Cholesterol efflux assay}

The treated macrophages were plated in 12-well plates and loaded with $40 \mu \mathrm{g} / \mathrm{ml}$ Dil-oxLDL for $48 \mathrm{~h}$ at room temperature. Then the medium was removed and cells were washed twice with PBS. The culture medium was then changed into RPMI1640 medium containing $0.1 \%$ BSA supplemented with apoAI $(10 \mu \mathrm{g} / \mathrm{ml}$, Novoprotein, China) or HDL (100 $\mu \mathrm{g} / \mathrm{ml}$, Jingke Chemistry, China) at $37^{\circ} \mathrm{C}$ for $24 \mathrm{~h}$. At the end of this incubation period, the supernatant was collected and centrifuged at 12,000 rpm for $10 \mathrm{~min}$ to remove debris. Cells were lysed with $0.5 \mathrm{~mL}$ of $0.1 \mathrm{~N} \mathrm{NaOH}$. The fluorescence in both the supernatant and cellular lipid was measured on a fluorescence microplate (Thermo Labsystems, USA). Fluorescence intensity was determined and expressed as a percentage of the total cell Dil-oxLDL content (effluxed Dil-oxLDL plus cell-associated Dil-oxLDL).

\section{Statistical analysis}

Data are expressed as mean \pm SD. Results were analyzed by oneway ANOVA followed by Fisher's LSD procedure using SPSS 21.0. $P<0.05$ was considered statistically significant. All experiments were performed at least three times.

\section{Results}

AGEs-induced up-regulation of RAGE expression in THP-1 macrophages

After incubation with AGEs at different concentrations $(300 \mu \mathrm{g} / \mathrm{ml}$ and $600 \mu \mathrm{g} / \mathrm{ml})$, RAGE expression was substantially up-regulated both in mRNA (Fig. 1a) and protein (Fig. 1b) compared with control group in a concentration-dependent manner. There were 3.0-fold increase in mRNA $(3.53 \pm 0.57$ vs $1.15 \pm 0.07, P=0.049)$ and 2.5 -fold increase in proteins $(2.52 \pm 0.49$ vs $1.02 \pm$ $0.01, P<0.001)$ compared with control group when the concentration of AGEs was $300 \mu \mathrm{g} / \mathrm{ml}$. As the concentration of AGEs reaching at $600 \mu \mathrm{g} / \mathrm{ml}$, increasement of RAGE expression was 17.0 times in mRNA $(19.5 \pm 0.43 v \mathrm{~s}$ $1.15 \pm 0.07, P<0.001)$ and 4.0 times in proteins $(4.07 \pm$ 0.43 vs $1.02 \pm 0.01, P<0.001)$ compared with control group. After pretreating with anti-RAGE antibody, RAGE expression was suppressed both in mRNA $(5.70 \pm 0.45$ vs $19.5 \pm 0.43, P<0.001)$ (Fig. 1a) and protein $(1.24 \pm 0.31 v s$
$4.07 \pm 0.43, P<0.001$ ) (Fig. 1b) compared with $600 \mu \mathrm{g} / \mathrm{ml}$ AGEs group.

\section{AGEs increase the oxLDL-induced lipid accumulation in THP-1 macrophages}

Intracellular lipid droplets were observed through oil red staining. As shown in Fig. 2a-d, AGEs-stimulated macrophages showed much more red-stained lipid droplets than the control group, especially in the group of $600 \mu \mathrm{g} / \mathrm{ml}$ AGEs. However, this trend was inhibited by anti-RAGE antibody pretreatment. The optical density (OD) value of each group which was normalized by the number of cells showed that there was significant change in $600 \mathrm{ug} / \mathrm{ml}$ AGEs group compared with control group and anti-RAGE antibody pretreated group (Fig. 2 e).

\section{AGEs increase lipid uptake in THP-1 macrophages by up-regulating CD36, SRA2 expression mediated by RAGE} To investigate the effects of AGEs on cholesterol uptake in macrophages, we examined cholesterol uptake using a Dil-oxLDL binding assay in response to the treatments with AGEs at the concentrations of $300 \mu \mathrm{g} / \mathrm{ml}$ and $600 \mu \mathrm{g} / \mathrm{ml}$ in THP-1 macrophages. As shown in Fig. 3a-c) and (e), AGEs at a concentration of $300 \mu \mathrm{g} / \mathrm{ml}$ did not significantly alter Dil-oxLDL binding to THP-1 macrophages $(0.093 \pm 0.012$ vs $0.085 \pm 0.012, P=0.335)$, while $600 \mu \mathrm{g} / \mathrm{ml}$ AGEs significantly increased oxLDL internalization in THP-1 macrophages $(0.156 \pm 0.023$ vs $0.085 \pm 0.012, P<0.001)$. Pretreatment with anti-RAGE antibody before adding AGEs in concentration of $600 \mu \mathrm{g} /$ $\mathrm{ml}$ reduced Dil-oxLDL binding to THP-1 macrophages compared with only AGEs $(0.103 \pm 0.013$ vs $0.156 \pm 0.023$, $P<0.001$ ) (Fig. 3d, e).

Macrophages phagocytose oxLDL through scavenger receptors, including $\mathrm{CD} 36$, and scavenger receptor $\mathrm{A}$, to form foam cells. To elucidate the molecular mechanism of AGEs on the accumulation of oxLDL in macrophages, we detected the expression of scavenger receptors, CD36 and SRA2. As depicted in Fig. 4, AGEs in concentration of $600 \mu \mathrm{g} / \mathrm{ml}$ can dramatically increase CD36 and SRA2 mRNA and protein levels $(P<0.05)$; whereas, those changes can't be observed in cells incubated with $300 \mu \mathrm{g} / \mathrm{ml}$ AGEs. The application of antibody of RAGE significantly suppressed the expression of CD36 and SRA2 both in mRNA and protein compared with only AGEs of $600 \mu \mathrm{g} / \mathrm{ml}$ $(P<0.05)$ (Fig. 4).

AGEs reduce $A B C G 1$-dependent cholesterol efflux to HDL through interaction with RAGE

We next investigated the effect of AGEs on cholesterol efflux. By using Dil-oxLDL, we found that AGEs in concentration of $600 \mu \mathrm{g} / \mathrm{ml}$ elicited a significant reduction in cholesterol efflux mediated by HDL but not apoAI, 


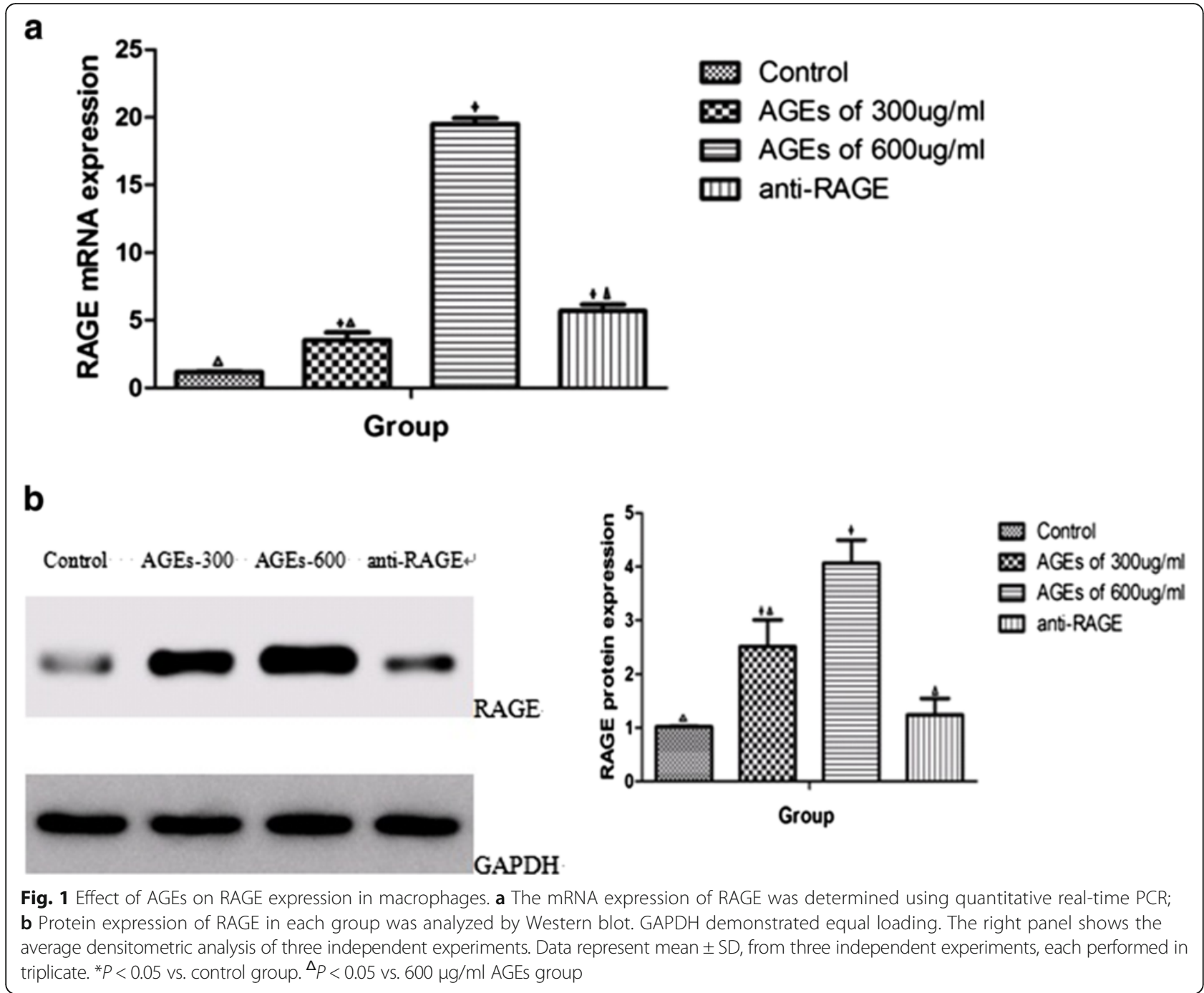

expressed as the percentage of total cell cholesterol released into the medium $(P<0.05)$. Treatment with antibody of RAGE significantly increased cholesterol efflux $(P<0.05)$. (Fig. 5)

Then we examined the expression of both ABCA1 and ABCG1 in macrophages. AGEs significantly reduced the mRNA expression of ABCG1 but not ABCA1 in concentration- depended manner $(300 \mu \mathrm{g} / \mathrm{ml}(0.38 \pm 0.03$ vs $1.15 \pm 0.07, P<0.001)$ and $600 \mu \mathrm{g} / \mathrm{ml}$ of AGEs $(0.09 \pm 0.01$ vs $1.15 \pm 0.07, P<0.001$ ) (Fig. 6a, b). Pretreating THP-1 macrophages with an anti-RAGE antibody significantly suppressed this effect (Fig. 6b). The expression of ABCG1 in protein was in accordance with that in mRNA (Fig. 6e).

Then we examined the potential involvement of transcription factors LXR- $\alpha$, known regulators of ABCA1 and ABCG1 expression in macrophages. We found that expression of LXR- $\alpha$ was up-regulated both in mRNA and in protein in incubation with AGEs, and the pretreatment with anti-RAGE antibody suppressed the effect (Fig. 6c, f).
AGEs increase cholesteryl ester formation by targeting ACAT1 and HMGCR through regulating RAGE expression We measured the levels of TC and FC by enzymatic assay kit and calculated the levels of CE. The data (Table 1) showed that $600 \mu \mathrm{g} / \mathrm{ml}$ of AGEs treatment increased CE levels compared with the control group $(P<0.001)$. However, pretreatment with anti-RAGE antibody inhibited AGEs-induced foam cell formation $(P<0.05)$. We further investigated the expression of HMGCR and ACAT-1, which were related with the endogenous synthesis and esterification of FC in THP-1 macrophages. AGEs significantly reduced ACAT1 mRNA expression in a high concentration of $600 \mu \mathrm{g} / \mathrm{ml}(8.15 \pm 1.45 \mathrm{vs}$ $1.15 \pm 0.07, P<0.001$ ) but reduced ACAT1 protein levels even in a low concentration of $300 \mu \mathrm{g} / \mathrm{ml}(4.93 \pm 0.23$ vs $1.02 \pm 0.06, P<0.001$ ) (Fig. $7 \mathrm{a}, \mathrm{c}$ ). The expressions of HMGCR in mRNA and protein were increased in concentration of $600 \mu \mathrm{g} / \mathrm{ml}$ of AGEs $(P<0.05)$ (Fig. 7b, d). Pretreatment with anti-RAGE antibody showed the 

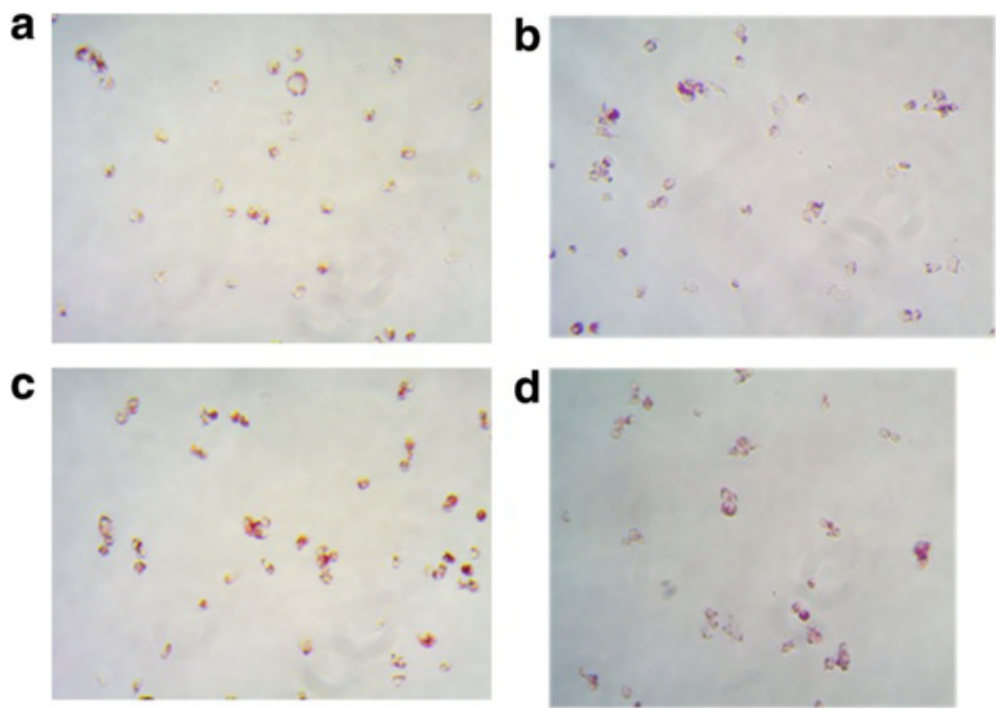

\section{e}

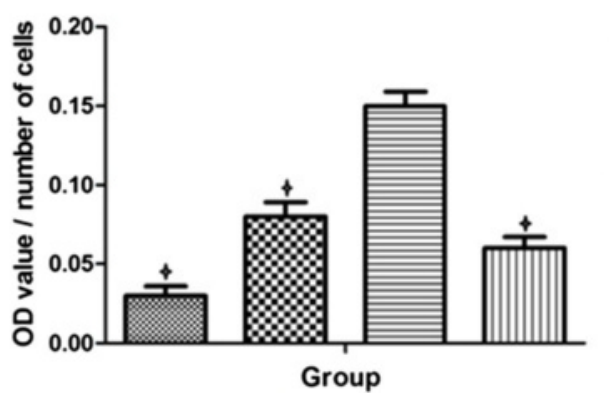

Fig. 2 AGEs increase lipid accumulation in macrophages in a concentration-dependent manner. a-d Representative images of oil red staining a control group; b AGEs of $300 \mu \mathrm{g} / \mathrm{ml}$ group; c AGEs of $600 \mu \mathrm{g} / \mathrm{ml}$ group; d AGEs of $600 \mu \mathrm{g} / \mathrm{ml}$ plus anti-RAGE antibody group. The magnification of each panel is 200x. e Quantification of Oil Red O stained cells as measured by the OD value at $518 \mathrm{~nm}$. The results were normalized as OD value/number of cells. Data represent mean \pm SD. from three independent experiments, each performed in triplicate. ${ }^{*} P<0.05 \mathrm{vs}$. $600 \mu \mathrm{g} / \mathrm{ml}$ AGEs group. One of three representative experiments is shown

opposite effect, significantly decreasing ACAT1 and HMGCR levels (Fig. 7a-d).

\section{Discussion}

The maintain of macrophage cholesterol homeostasis is of great importance in the prevention of atherosclerosis. Dysregulation of the balance of cholesterol influx, endogenous synthesis, esterification/hydrolysis, and cholesterol efflux leads to excessive accumulation of cholesterol in macrophages and their transformation into foam cells and death [15]. In the present study, we elucidated the underlying mechanisms of AGEs-RAGE regulated cellular influx, intracellular esterification/hydrolysis and efflux of cholesterol. Our results provide strong evidence that AGEs-RAGE interaction may regulate the processes of cholesterol homeostasis from influx to efflux by increasing the expression of SRA2, CD36, ACAT1, HMGCR and decreasing expression of ABCG1 in macrophages.

There is increasing evidence that AGEs and their interaction with RAGE play a pivotal role in atherosclerosis, in particular in the setting of diabetes. AGEs binding to RAGE activates various signalling pathways, including NADPH oxidases, mitogen-activated protein kinases (MAPKs), p21 ${ }^{\text {ras }}$, ERK p38 and protein kinase C (PKC), and finally leads to sustained cellular dysfunction driven by long-term activation of the nuclear factor-kB (NFkB) $[27,28]$. The importance of AGEs as downstream mediators of hyperglycaemia in diabetes has been amply demonstrated by animal studies using inhibitors of advanced glycation to retard the development of vascular disease without directly influencing plasma glucose levels $[29,30]$. Furthermore, dietary excess of AGEs has been shown to accelerate atherosclerosis without affecting glycaemic control [31]. Studies in vivo showed that administration of soluble RAGE (sRAGE), a truncated form of RAGE acting as a decoy for AGE, completely suppressed diabetic atherosclerosis in glycemia- and lipid-independent manners [13]. In diabetesassociated atherosclerosis models, RAGE overexpression in transgenic mice was associated with increased vascular 
a

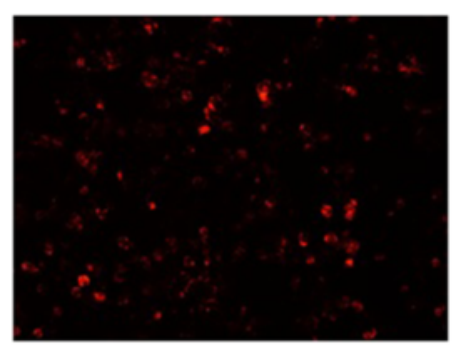

C

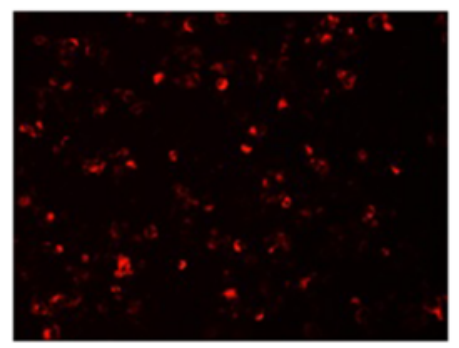

e

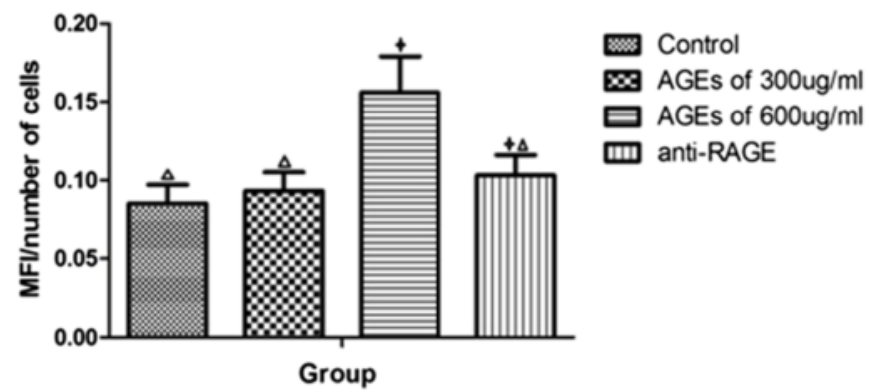

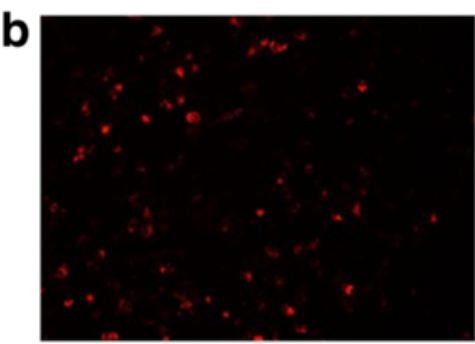

d

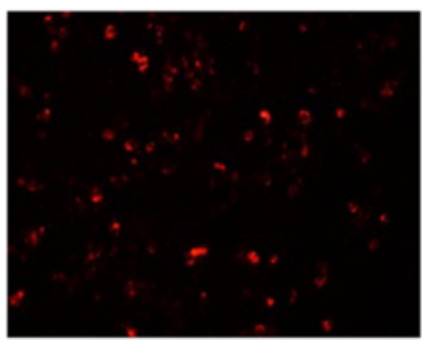

Control

AGEs of $300 u g / m$

AGEs of $600 \mathrm{ug} / \mathrm{ml}$

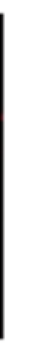




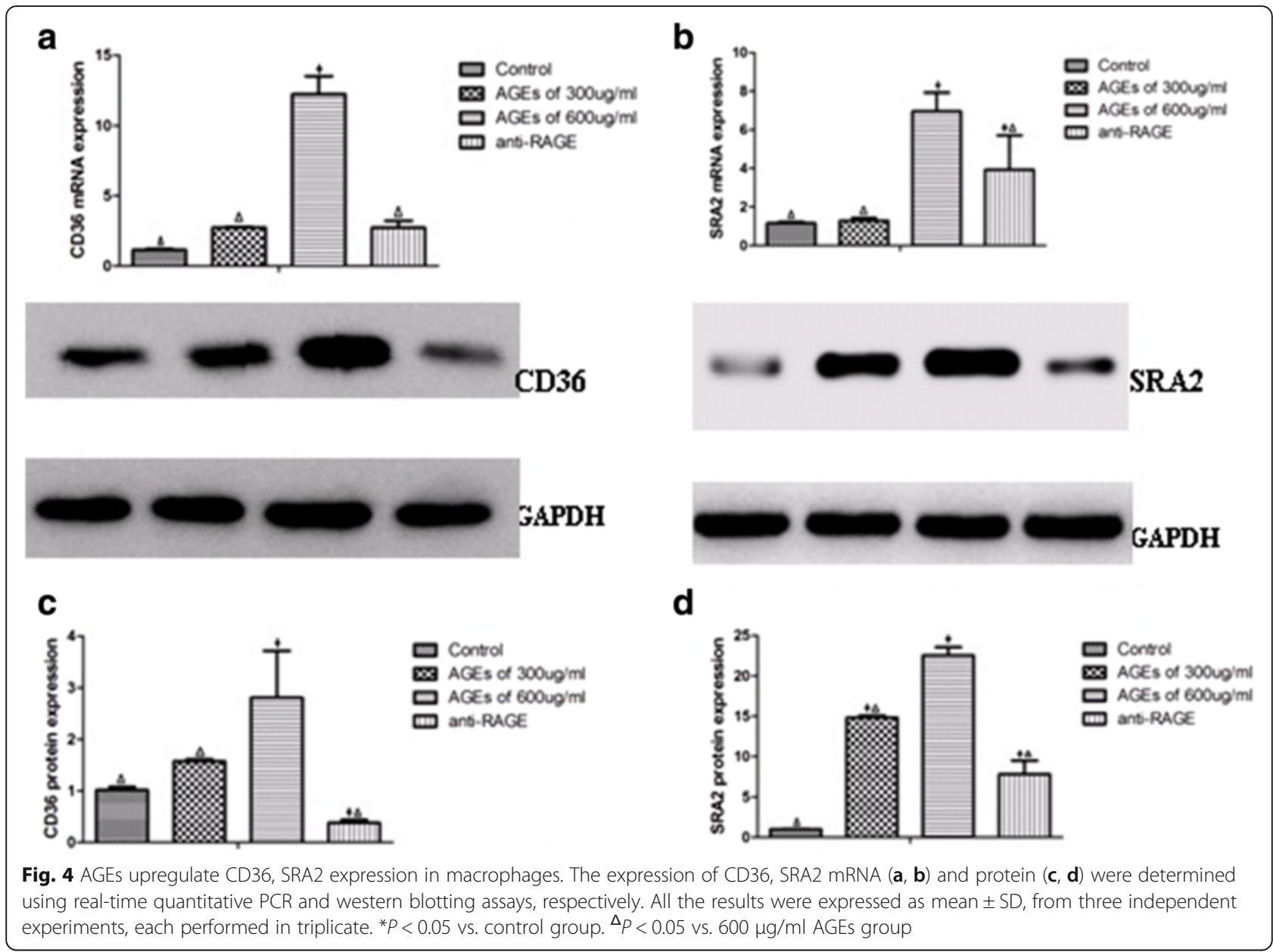

via PPAR- $\gamma$ dependent signaling pathway, and SRA-2 is mainly regulated by PPAR- $\gamma$ and NF-kB signaling pathway [33]. Activation of RAGE with AGEs leads to the production of reactive oxygen (ROS) and nitrogen species (RNS) by a variety of mechanisms, which may activates the PPAR- $\gamma$ and NF-kB signaling pathway [24] [36]. It may be the molecular mechanism for upregulation of CD36 and SRA2 by AGEs-RAGE interaction.
The results of cholesterol efflux assay in our study showed that AGEs can reduce cholesterol efflux through HDL but not apo AI in macrophages. When blocking AGEs-RAGE interaction by anti-RAGE antibody, the decrease of cholesterol efflux would recover. It is confirmed that AGEs have deleterious effects on cholesterol efflux in macrophages through binding with RAGE. Then we determined the transporters associated

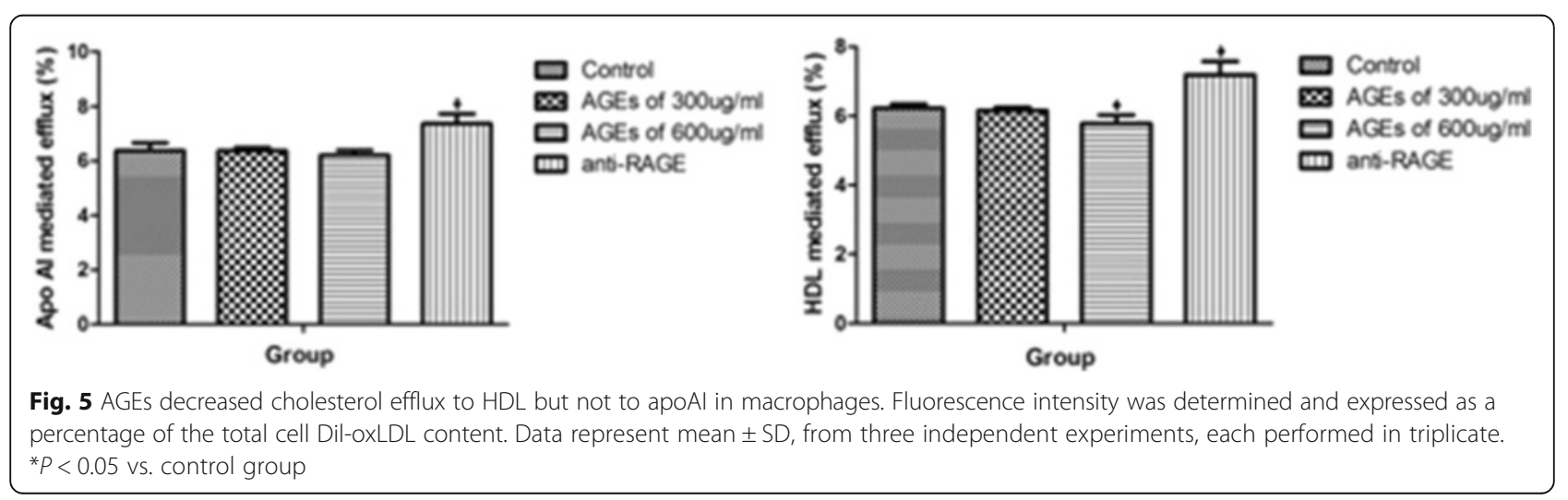



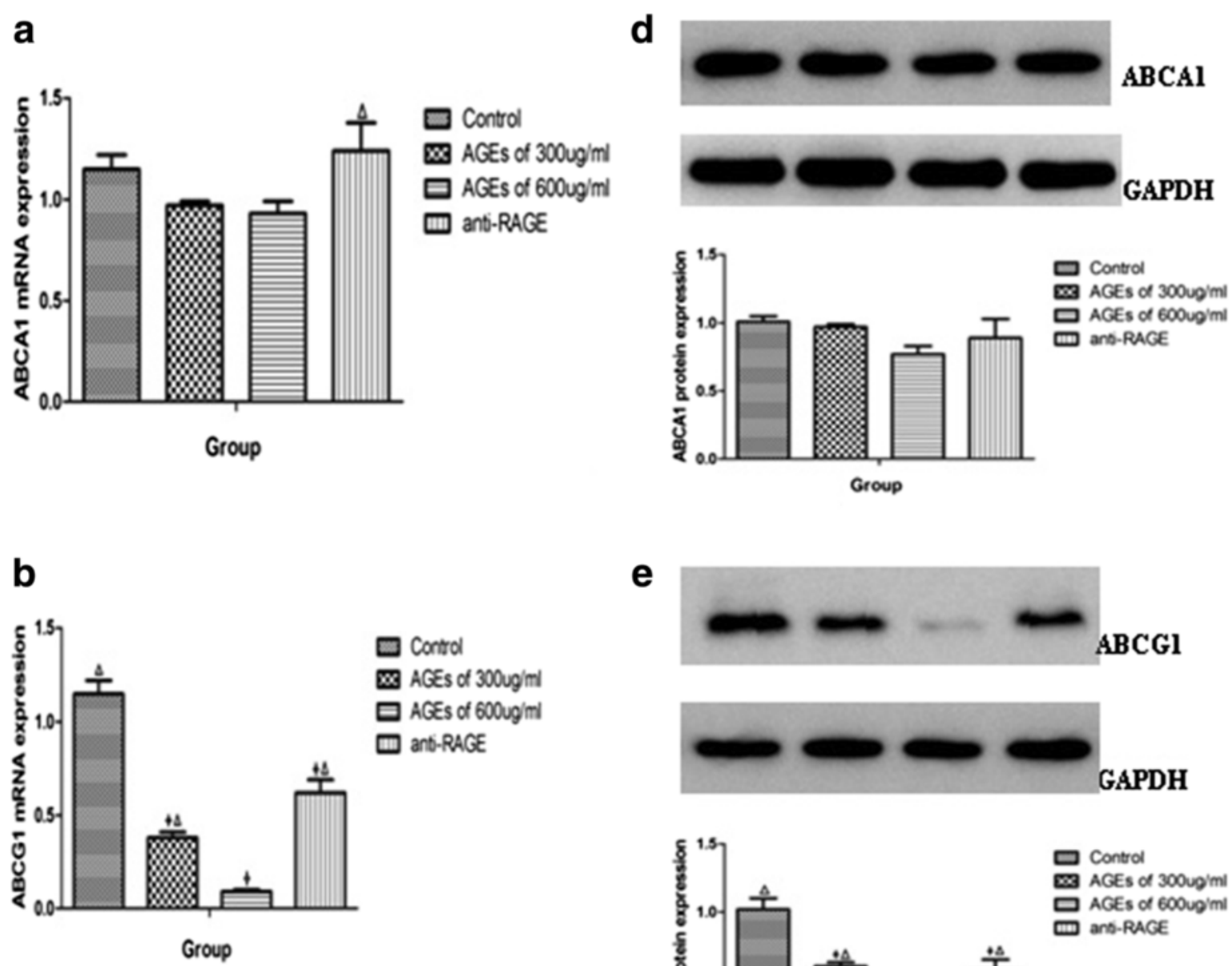

e
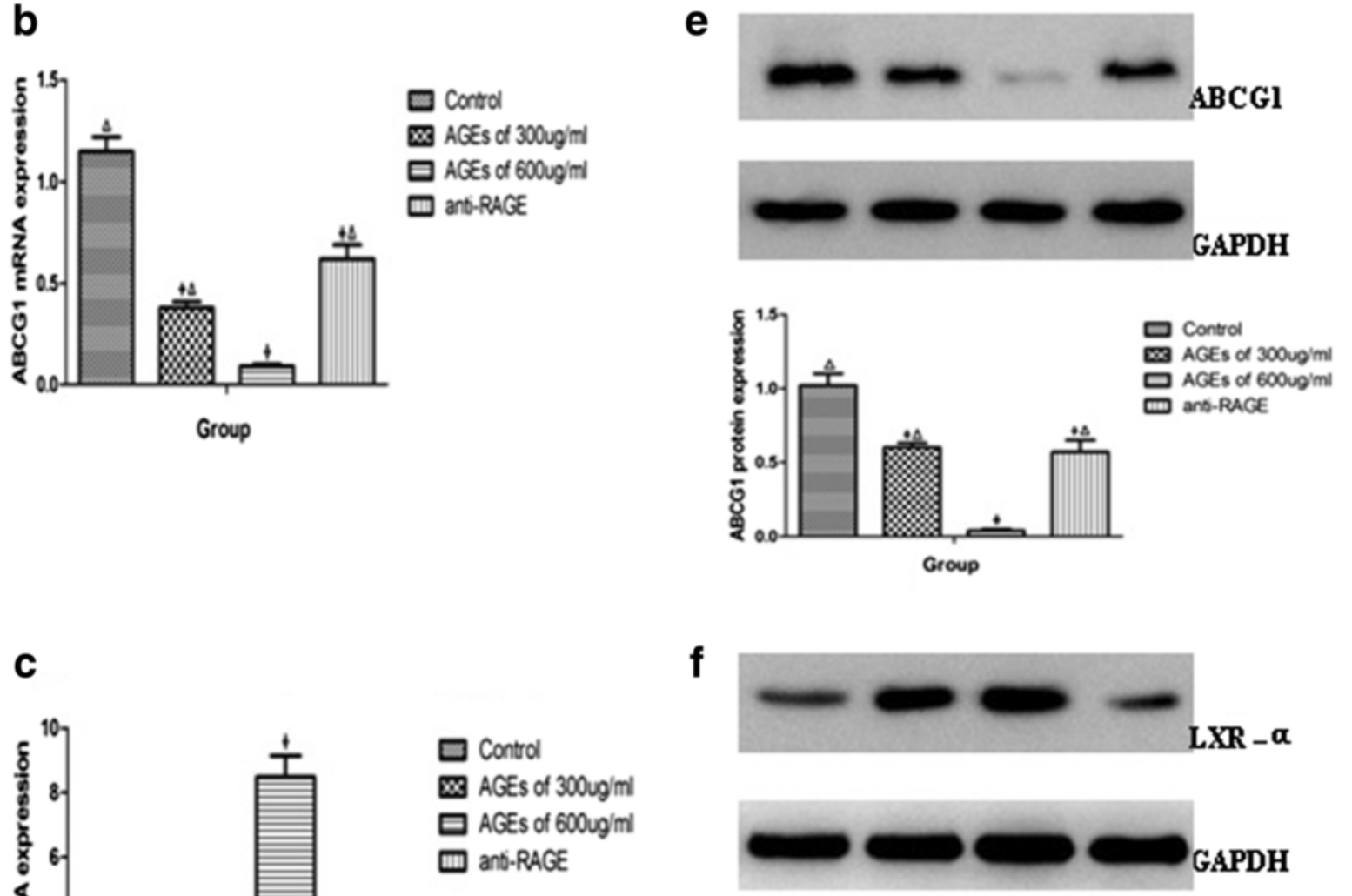

f
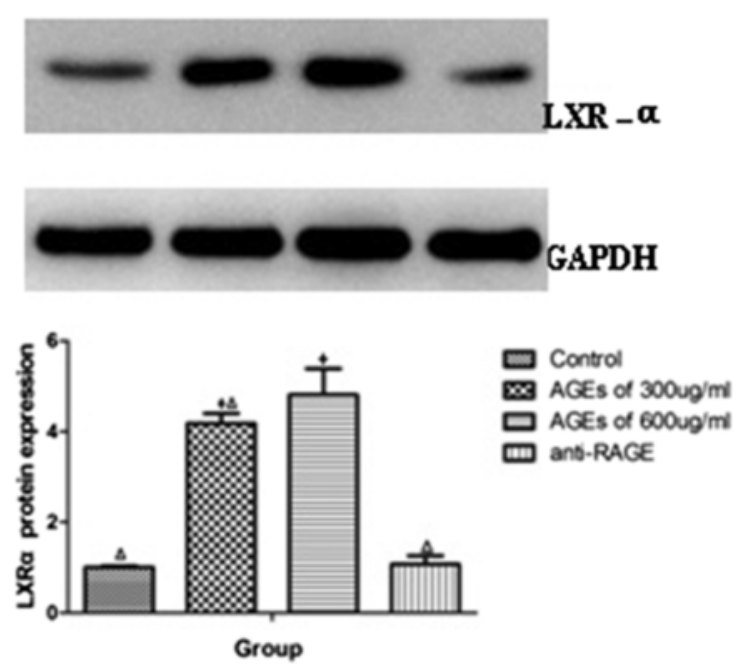

Fig. 6 AGEs downregulate ABCG1 expression in macrophages. The expression of ABCA1, ABCG1, LXR-a mRNA (a-c) and protein (d-f) were determined using real-time quantitative PCR and western blotting assays, respectively. All the results are expressed as mean $\pm S D$, from three independent experiments, each performed in triplicate. ${ }^{*} P<0.05$ vs. control group. ${ }^{\Delta} P<0.05 \mathrm{vs}$. $600 \mathrm{\mu g} / \mathrm{ml}$ of AGEs group 
Table 1 Effects of AGEs on cholesterol content in macrophages. (ng/ $\mu \mathrm{g}$ protein)

\begin{tabular}{lllll}
\hline & Control & $300 \mu \mathrm{g} / \mathrm{ml}$ of AGEs & $600 \mu \mathrm{g} / \mathrm{ml}$ of AGEs & $600 \mu \mathrm{g} / \mathrm{ml}$ of AGEs + Anti-RAGE antibody \\
\hline TC & $197.13 \pm 22.1^{* *}$ & $234.43 \pm 11.23^{* *}$ & $652.61 \pm 11.76^{*}$ & $407.78 \pm 33.98^{*, * *}$ \\
FC & $163.21 \pm 7.42^{* *}$ & $201.83 \pm 12.44^{* *}$ & $458.70 \pm 29.14^{*}$ & $284.20 \pm 33.57^{* * * *}$ \\
CE & $33.92 \pm 29.49^{* *}$ & $32.6 \pm 20.02^{* *}$ & $193.91 \pm 31.39^{*}$ & $123.58 \pm 65.19^{*, * *}$ \\
\hline
\end{tabular}

Data are expressed as mean \pm S.D. ${ }^{*} P<0.05$ vs. control group, ${ }^{* *} P<0.05$ vs. $600 \mu \mathrm{g} / \mathrm{ml}$ of AGEs group

with cholesterol efflux and found that AGEs decreased ABCG1 mRNA and protein levels in macrophages in a RAGE-dependent manner.

Reverse cholesterol transport ( $\mathrm{RCT}$ ) is the primary pathway for the removal of excess cholesterol and involves lipid transporters such as ABCA1 and ABCG1 that mediate the transfer of cholesterol from peripheral cells to selected extracellular acceptors [37, 38]. The full ABC transporter $\mathrm{ABCA} 1$ appears most effective at mediating cholesterol efflux to apoAI as acceptor [39, 40]. The

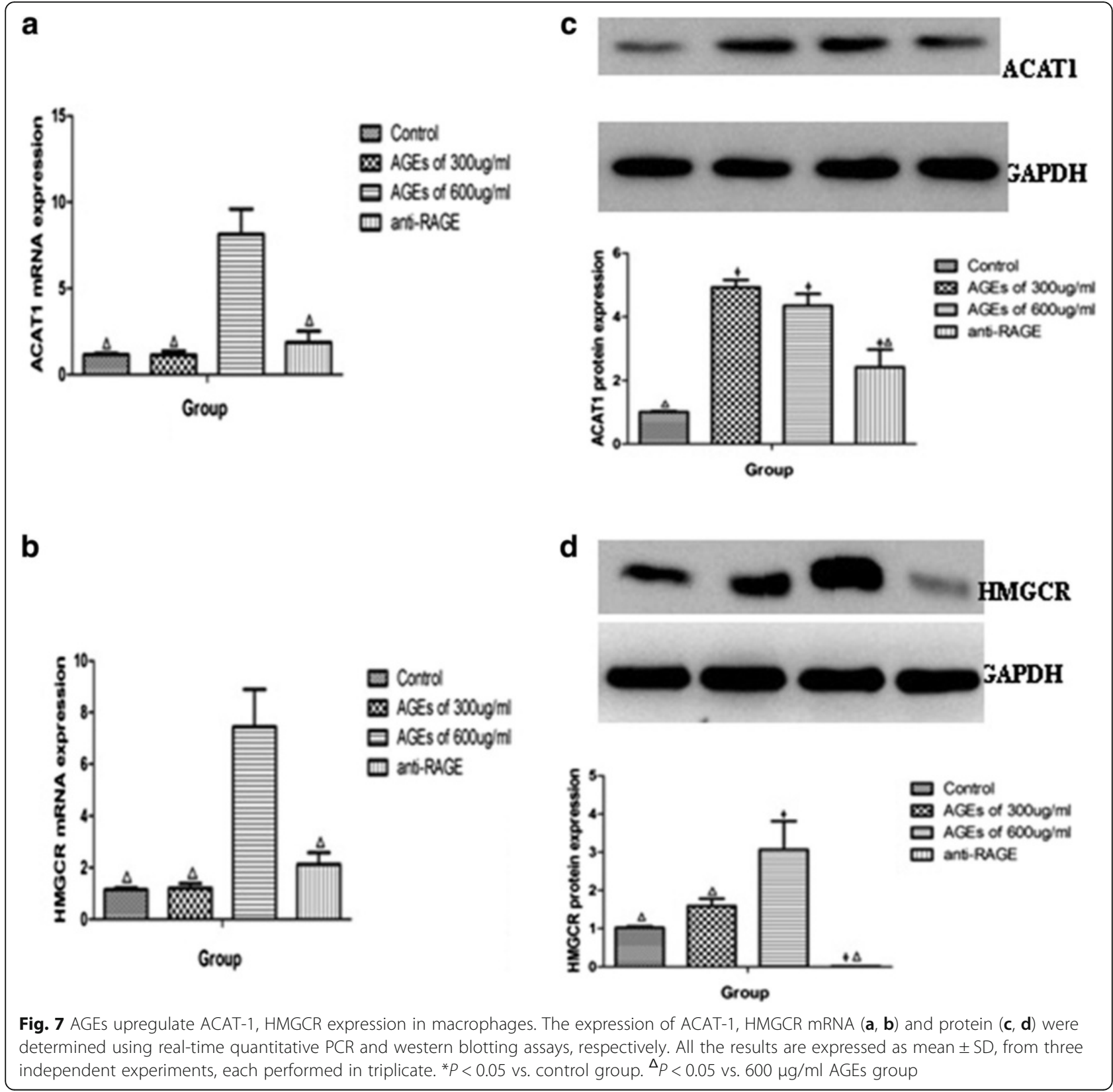


"half transporter" ABCG1 also facilitates cholesterol efflux from macrophages, preferring HDL as acceptor [41, 42]. LXR can control the expression of both ABCA1 and ABCG1 [43], and several recent reports suggest that both transporters share similar transcriptional control mechanisms [44, 45]. The effects of AGEs-RAGE axis on $\mathrm{ABC}$ transporters reported in previous studies are contradictory. The results of Passarelli $\mathrm{M}$ et al. [46] have shown that AGEs can impair cholesterol efflux from cultured human fibroblasts and murine macrophages through suppressing ABCA1 expression [46]. However, Isoda $\mathrm{K}$ et al. [47] reported that AGEs reduced macrophage cholesterol efflux to HDL through decreasing ABCG1 expression in a LXR- $\alpha$ independent way [47]. Recent study from Daffu G et al. [48] have demonstrated that RAGE suppressed macrophage cholesterol efflux in diabetic animal models and several different cell lines by moderately upregulating ABCA1 expression and significantly upregulating ABCG1 expression in a LXR $\alpha$-independent way [48]. Our results were more like Daffu G's that ABCA1 expression was slightly changed without statistical significance after treatment, while ABCG1 expression was dramatically changed with obviously statistical significance. LXR- $\alpha$ expression was contrary to both ABCA1 and ABCG1. So we report here that AGEs mainly reduces the expression of ABCG1 but not ABCA1 in a LXR $\alpha$-independent manner in THP1 macrophages, supporting the notion that ABCG1 may be especially important in diabetic atherosclerosis and providing a novel mechanistic insight into the relationship between HDL and atherosclerosis risk in diabetic patients. Our results also provide evidence that there are other signaling pathway to regulate expression of ABCG1 except LXR- $\alpha$. Peroxisome proliferator response elements (PPRE) in the promoter regions of target genes is recognized as a important regulator which can binging with PPAR- $\gamma$ to activate transcription [49]. It has been demonstrated that RAGE ligands suppressed ABCG1 and ABCA1 promoter luciferase activity and transcription of ABCG1 and ABCA1 through PPRE but not LXR elements [48]. So it can be speculated from our results that AGEs-RAGE axis may regulate ABCG1 expression mainly through PPRE binding with PPAR- $\gamma$, while ABCA1 expression may be mainly controlled by classical PPAR- $\gamma / \mathrm{LXR}-\alpha$ signaling pathway which is less affected by AGEs-RAGE axis. Besides PPRE, previous findings suggest a hitherto unsuspected degree of complexity in the regulation of the ABCG1 gene. The human ABCG1 gene spans $97 \mathrm{~kb}$ comprising 20 exons, potentially giving rise to multiple transcripts, and further contains two promoters with binding sites for multiple transcription factors, including NF-kB and sterol regulatory element-binding protein (SREBP) [50]. Both SREBP and NF-kB have been shown to be involved in the coactivation of transcription of genes involved in cholesterol metabolism [51]. Such structural complexity raise speculation about the potential mechanism that AGEs-RAGE axis interfere with the expression of ABCG1 through NF-kB and SREBP signaling pathway. Further studies will be required to elucidate the details of AGEs-RAGE-NF-kB/ SREBP-ABCG1 regulating pathway.

In the process of foam cell formation, ACAT1 re-esterifies excess FC to promote the biosynthesis of CE that is stored in lipid droplets [52]. In this study, we found that AGEs increased cellular CE levels. Furthermore, we demonstrated that high concentration of AGEs targeted expression of ACAT1, regulated the mRNA and protein levels of ACAT1, and increased $\mathrm{CE}$ formation in macrophage-derived foam cells. In contrast, low concentration of AGEs increased the protein expression of ACAT1 but had no effect on its mRNA expression, which can't be explained by present study. However, it should be noted that ACAT1 protein increased similarly after treatment with 300 and $600 \mu \mathrm{g} / \mathrm{ml}$ AGEs, but the CE levels didn't increase over control at $300 \mu \mathrm{g} / \mathrm{ml}$ AGEs. The possible reseason for that may be the difference of internalization of lipoproteins by macrophages between 300 and $600 \mu \mathrm{g} / \mathrm{ml}$ AGEs group. Besides, we didn't detect the expression of nCEH which hydrolyzes CE to cholesterol for efflux out of the cells. The changes of nCEH caused by different concentration of AGEs can also affect the levels of CE. In addition to uptake of extracellular lipoprotein, another main sources of intracellular FC are endogenous synthesis, which is regulated by HMGCR, a rate-limiting enzyme in the pathway for cholesterol synthesis [53]. Our study have demonstrated that AGEs can upregulate expression of HMGCR which can increase intracellular cholesterol and promote CE formation. Both ACAT1 expression and HMGCR expression decreased when using anti-RAGE antibody to pretreat, which indicated that the role of AGEs in upregulating ACAT1 and HMGCR needed to bind with RAGE. SREBP2 is probably the key factor connecting AGEs/RAGE with ACAT1/HMGCR [54].

\section{Conclusions}

In conclusion, the present study shows that AGEs increase lipids accumulation in macrophages probably by upregulating RAGE expression. The whole process of foam cell formation including cholesterol influx, synthesis and efflux in macrophage can be affected by AGEs-RAGE interaction. Our study provide a deep understanding how AGEs can accelerate diabetic atherogenesis and suggest that drugs for anti-AGEs, downregulating expression of RAGE or blocking AGEs binding with RAGE may be useful adjunctive therapeutic agents in the management of diabetic atherosclerosis especially in the early stage to prevent foam cell formation. According to the results that most of the changes induced by AGEs are concentration dependent, our study emphasize the importance of good blood glucose control which can reduce AGEs levels both 
in blood serum and in arterial wall in prevention of diabetic atherosclerosis. It is also indicated that HDL may have special meaning for diabetic patients compare with non-diabetic people. Further studies need to be done to understand the detailed signaling pathways whereby AGEs-RAGE breaks the homeostasis of cholesterol metabolism in macrophages.

\begin{abstract}
Abbreviations
ABCA1: ATP-binding cassette transporter A1; ABCG1: ATP-binding cassette transporter G1; AGEs: Advanced glycation end products; CE: Esterified cholesterol; Dil: 1,1'-dioctadecyl- 3,3,3',3' -tetramethylin docarbocyaninet; FC: Free cholesterol; HMGCR: HMG-CoA reductase; LXR: Liver X receptor; MAPKs: mitogen-activated protein kinases; MFI: Mean fluorescence intensity; nCEH: Cholesteryl ester hydrolase; NF-kB: Nuclear factor-kB; OD: Optical density; oxLDL: oxidized-LDL; PKC: Protein kinase C; PPRE: Peroxisome proliferator response elements; RAGE: Receptor of advanced glycation end products; SR: Scavenger receptors; SREBP: Sterol regulatory element-binding protein; TC: Total cholesterol
\end{abstract}

\section{Acknowledgements}

This work was supported by grants from National Natural Science Foundation of China (81300699), foundation of Shanghai Municipal Health and Family Planning Commission (20124Y106), and Program foundation for young medical talents in Pudong New District of Shanghai, China (PWRq2013-04). The content is solely the responsibility of the authors and does not necessarily represent the official views of the National Institutes of Health.

\section{Funding}

Not applicable.

\section{Availability of data and materials}

The datasets during and/or analysed during the current study available from the corresponding author on reasonable request.

\section{Authors' contributions}

LX carried out most of the experiments, interpreted the data and drafted the manuscript. YRW carried out the cell culture and treatment studies. PCL carried out interpretation of the data and statistical analysis. BF conceived the study, participated in its design and coordination, corrected the manuscript and supervised the study. All authors read and approved the final manuscript.

\section{Competing interests}

The authors declare that they have no competing interests.

\section{Consent for publication}

Not applicable.

\section{Ethics approval and consent to participate}

Not applicable.

\section{Author details}

'Department of Endocriology and Metabolic Disease, East Hospital, Tongji University School of Medicine, Shanghai 200120, China. ${ }^{2}$ Tongji University School of Medicine, Shanghai 200120, China. ${ }^{3}$ Ji-mo Road 150, Shanghai 200120, China.

Received: 27 July 2016 Accepted: 14 September 2016

Published online: 19 September 2016

\section{References}

1. Grundy SM, Benjamin IJ, Burke GL, Chait A, Eckel RH, Howard BV, et al. Diabetes and cardiovascular disease: a statement for healthcare professionals from the American Heart Association. Circulation. 1999;100:1134-46.

2. Pyorala K, Uusitupa M, Laakso M, Siitonen O, Niskanen L, Ronnemaa T. Macrovascular complications in relation to hyperinsulinaemia in non- insulindependent diabetes mellitus. Diabete Metab. 1987;13:345-9.

3. Candido R, Jandeleit-Dahm KA, Cao Z, Nesteroff SP, Burns WC, Twigg SM, et al. Prevention of accelerated atherosclerosis by angiotensin-converting enzyme inhibition in diabetic apolipoprotein E-deficient mice. Circulation. 2002;106:246-53.

4. Forbes JM, Yee LT, Thallas V, Lassila M, Candido R, Jandeleit-Dahm KA, et al. Advanced glycation end product interventions reduce diabetes-accelerated atherosclerosis. Diabetes. 2004;53:1813-23.

5. Goldberg IJ. Why does diabetes increase atherosclerosis? I don't know! J Clin Invest. 2004;114:613-5.

6. Bierhaus A, Hofmann MA, Ziegler R, Nawroth PP. AGEs and their interaction with AGE-receptors in vascular disease and diabetes mellitus. I. The AGE concept. Cardiovasc Res. 1998;37:586-600.

7. Falcone C, Emanuele E, D'Angelo A, Buzzi MP, Belvito C, Cuccia M, et al. Plasma levels of soluble receptor for advanced glycation end products and coronary artery disease in nondiabetic men. Arterioscler Thromb Vasc Biol. 2005;25:1032-7.

8. Baynes JW, Thorpe SR. Glycoxidation and lipoxidation in atherogenesis. Free Radic Biol Med. 2000;28:1708-16.

9. Sano H, Nagai R, Matsumoto K, Horiuchi S. Receptors for proteins modified by advanced glycation endproducts (AGE)-their functional role in atherosclerosis. Mech Ageing Dev. 1999;107:333-46.

10. Wautier MP, Chappey O, Corda S, Stern DM, Schmidt AM, Wautier JL. Activation of NADPH oxidase by AGE links oxidant stress to altered gene expression via RAGE. Am J Physiol Endocrinol Metab. 2001;280:E685-94.

11. Schmidt AM, Yan SD, Yan SF, Stern DM. The multiligand receptor RAGE as a progression factor amplifying immune and inflammatory responses. J Clin Invest. 2001;108:949-55.

12. Hori O, Brett J, Slattery T, Cao R, Zhang J, Chen JX, et al. The receptor for advanced glycation end products (RAGE) is a cellular binding site for amphoterin. Mediation of neurite outgrowth and co-expression of rage and amphoterin in the developing nervous system. J Biol Chem. 1995;270:25752-61.

13. Bucciarelli LG, Wendt T, Qu W, Lu Y, Lalla E, Rong LL, et al. RAGE blockade stabilizes established atherosclerosis in diabetic apolipoprotein E-null mice. Circulation. 2002;106:2827-35.

14. Cuccurullo C, lezzi A, Fazia ML, De Cesare D, Di Francesco A, Muraro R, et al. Suppression of RAGE as a basis of simvastatin-dependent plaque stabilization in type 2 diabetes. Arterioscler Thromb Vasc Biol. 2006;26:2716-23.

15. Pennings M, Meurs I, Ye D, Out R, Hoekstra M, Van Berkel TJ, et al. Regulation of cholesterol homeostasis in macrophages and consequences for atherosclerotic lesion development. FEBS Lett. 2006;580:5588-96.

16. Collot-Teixeira S, Martin J, McDermott-Roe C, Poston R, McGregor JL. Cardiovasc Res. 2007;75:468-77.

17. Ghosh S, Zhao B, Bie J, Song J. Macrophage cholesteryl ester mobilization and atherosclerosis. Vascul Pharmacol. 2010;52:1-10.

18. Jessup W, Gelissen IC, Gaus K, Kritharides L. Roles of ATP binding cassette transporters A1 and G1, scavenger receptor Bl and membrane lipid domains in cholesterol export from macrophages. Curr Opin Lipidol. 2006;17:247-57.

19. Chawla A, Boisvert WA, Lee CH, Laffitte BA, Barak Y, Joseph SB, et al. A PPAR gamma-LXR-ABCA1 pathway in macrophages is involved in cholesterol efflux and atherogenesis. Mol Cell. 2001;7:161-71.

20. Goldstein JL, Brown MS. Regulation of the mevalonate pathway. Nature. 1990;343:425-30.

21. Wang N, Ranalletta M, Matsuura F, Peng F, Tall AR. LXR-induced redistribution of ABCG1 to plasma membrane in macrophages enhances cholesterol mass efflux to HDL. Arterioscler Thromb Vasc Biol. 2006;26:1310-6.

22. Tuomisto TT, Korkeela A, Rutanen J, Viita H, Brasen JH, Riekkinen MS, et al. Gene expression in macrophage-rich inflammatory cell infiltrates in human atherosclerotic lesions as studied by laser microdissection and DNA array: overexpression of HMG-CoA reductase, colony stimulating factor receptors, CD11A/CD18 integrins, and interleukin receptors. Arterioscler Thromb Vasc Biol. 2003;23:2235-40.

23. Feng $B, X u$ L, Wang $H$, Yan $X$, Xue J, Liu F, et al. Atorvastatin exerts its anti-atherosclerotic effects by targeting the receptor for advanced glycation end products. Biochim Biophys Acta. 1812;2011:1130-7.

24. Farmer DG, Kennedy S. RAGE, vascular tone and vascular disease. Pharmacol Ther. 2009;124:185-94.

25. Wang XQ, Yang K, He YS, Lu L, Shen WF. Receptor mediated elevation in FABP4 levels by advanced glycation end products induces cholesterol and triacylglycerol accumulation in THP-1 macrophages. Lipids. 2011;46:479-86.

26. Yuan Y, Zhao L, Chen Y, Moorhead JF, Varghese Z, Powis SH, et al. Advanced glycation end products (AGEs) increase human mesangial foam cell formation by increasing Golgi SCAP glycosylation in vitro. Am J Physiol Renal Physiol. 2011;301:F236-43. 
27. Li JH, Wang W, Huang XR, Oldfield M, Schmidt AM, Cooper ME, et al. Advanced glycation end products induce tubular epithelial-myofibroblast transition through the RAGE-ERK1/2 MAP kinase signaling pathway. Am J Pathol. 2004;164:1389-97.

28. Liliensiek B, Weigand MA, Bierhaus A, Nicklas W, Kasper M, Hofer S, et al. Receptor for advanced glycation end products (RAGE) regulates sepsis but not the adaptive immune response. J Clin Invest. 2004;113:1641-50.

29. Forbes JM, Thallas $V$, Thomas MC, Founds HW, Burns WC, Jerums G, et al. The breakdown of preexisting advanced glycation end products is associated with reduced renal fibrosis in experimental diabetes. Faseb j. 2003;17:1762-4

30. Soulis T, Thallas V, Youssef S, Gilbert RE, McWilliam BG, Murray-McIntosh RP, et al. Advanced glycation end products and their receptors co-localise in rat organs susceptible to diabetic microvascular injury. Diabetologia. 1997;40:619-28.

31. Lin RY, Choudhury RP, Cai W, Lu M, Fallon JT, Fisher EA, et al. Dietary glycotoxins promote diabetic atherosclerosis in apolipoprotein E-deficient mice. Atherosclerosis. 2003;168:213-20.

32. Soro-Paavonen A, Watson AM, Li J, Paavonen K, Koitka A, Calkin AC, et al. Receptor for advanced glycation end products (RAGE) deficiency attenuates the development of atherosclerosis in diabetes. Diabetes. 2008;57:2461-9.

33. Kunjathoor W, Febbraio M, Podrez EA, Moore KJ, Andersson L, Koehn S, et al. Scavenger receptors class $\mathrm{A}-\mathrm{l} / \mathrm{II}$ and CD36 are the principal receptors responsible for the uptake of modified low density lipoprotein leading to lipid loading in macrophages. J Biol Chem. 2002;277:49982-8.

34. Araki N, Higashi T, Mori T, Shibayama R, Kawabe Y, Kodama T, et al. Macrophage scavenger receptor mediates the endocytic uptake and degradation of advanced glycation end products of the Maillard reaction. Eur J Biochem. 1995;230:408-15.

35. Ohgami N, Nagai R, Ikemoto M, Arai H, Kuniyasu A, Horiuchi S, et al. CD36, a member of class B scavenger receptor family, is a receptor for advanced glycation end products. Ann N Y Acad Sci. 2001;947:350-5.

36. Mahajan N, Dhawan V. Receptor for advanced glycation end products (RAGE) in vascular and inflammatory diseases. Int J Cardiol. 2013;168:1788-94.

37. Ono K. Current concept of reverse cholesterol transport and novel strategy for atheroprotection. J Cardiol. 2012;60:339-43.

38. Phillips MC. Molecular mechanisms of cellular cholesterol efflux. J Biol Chem. 2014;289:24020-9.

39. Bochem AE, van Wijk DF, Holleboom AG, Duivenvoorden R, Motazacker MM, Dallinga-Thie $\mathrm{GM}$, et al. ABCA1 mutation carriers with low high-density lipoprotein cholesterol are characterized by a larger atherosclerotic burden. Eur Heart J. 2013;34:286-91.

40. Zhao Y, Pennings M, Vrins CL, Calpe-Berdiel L, Hoekstra M, Kruijt JK, et al. Hypocholesterolemia, foam cell accumulation, but no atherosclerosis in mice lacking $\mathrm{ABC}$-transporter $\mathrm{A} 1$ and scavenger receptor $\mathrm{BI}$. Atherosclerosis. 2011;218:314-22.

41. Schou J, Frikke-Schmidt R, Kardassis D, Thymiakou E, Nordestgaard BG, Jensen $\mathrm{G}$, et al. Genetic variation in ABCG1 and risk of myocardial infarction and ischemic heart disease. Arterioscler Thromb Vasc Biol. 2012;32:506-15.

42. Out R, Hoekstra M, Hildebrand RB, Kruit JK, Meurs I, Li Z, et al. Macrophage ABCG1 deletion disrupts lipid homeostasis in alveolar macrophages and moderately influences atherosclerotic lesion development in LDL receptordeficient mice. Arterioscler Thromb Vasc Biol. 2006;26:2295-300.

43. Brewer Jr HB, Santamarina-Fojo S. Clinical significance of high-density lipoproteins and the development of atherosclerosis: focus on the role of the adenosine triphosphate-binding cassette protein A1 transporter. Am J Cardiol. 2003;92:10k-6.

44. Porsch-Ozcurumez M, Langmann T, Heimerl S, Borsukova H, Kaminski WE, Drobnik W, et al. The zinc finger protein 202 (ZNF202) is a transcriptional repressor of ATP binding cassette transporter $A 1$ (ABCA1) and ABCG1 gene expression and a modulator of cellular lipid efflux. J Biol Chem. 2001;276:12427-33.

45. Costet $P$, Luo $Y$, Wang N, Tall AR. Sterol-dependent transactivation of the $A B C 1$ promoter by the liver $X$ receptor/retinoid $X$ receptor. J Biol Chem. 2000;275:28240-5.

46. Passarelli M, Tang C, McDonald TO, O'Brien KD, Gerrity RG, Heinecke JW, et al. Advanced glycation end product precursors impair ABCA1-dependent cholesterol removal from cells. Diabetes. 2005;54:2198-205.

47. Isoda K, Folco EJ, Shimizu K, Libby P. AGE-BSA decreases ABCG1 expression and reduces macrophage cholesterol efflux to HDL. Atherosclerosis. 2007;192:298-304.
48. Daffu G, Shen X, Senatus L, Thiagarajan D, Abedini A, Hurtado Del Pozo C, et al. RAGE Suppresses ABCG1-Mediated Macrophage Cholesterol Efflux in Diabetes. Diabetes. 2015;64:4046-60.

49. Schrader M, Costello JL, Godinho LF, Azadi AS, Islinger M. Proliferation and fission of peroxisomes - An update. Biochim Biophys Acta. 1863;2016:971-83.

50. Lorkowski S, Rust S, Engel T, Jung E, Tegelkamp K, Galinski EA, et al. Genomic sequence and structure of the human ABCG1 (ABC8) gene. Biochem Biophys Res Commun. 2001;280:121-31.

51. Osborne TF, LaMorte VJ. Molecular aspects in feedback regulation of gene expression by cholesterol in mammalian cells. Methods. 1998;16:42-8.

52. Ouimet $M$, Marcel $Y L$. Regulation of lipid droplet cholesterol efflux from macrophage foam cells. Arterioscler Thromb Vasc Biol. 2012;32:575-81.

53. Brown MS, Goldstein JL. The SREBP pathway: regulation of cholesterol metabolism by proteolysis of a membrane-bound transcription factor. Cell. 1997;89:331-40.

54. Mastrocola R, Collino M, Rogazzo M, Medana C, Nigro D, Boccuzzi G, et al. Advanced glycation end products promote hepatosteatosis by interfering with SCAP-SREBP pathway in fructose-drinking mice. Am J Physiol Gastrointest Liver Physiol. 2013;305:G398-407.

\section{Submit your next manuscript to BioMed Central and we will help you at every step:}

- We accept pre-submission inquiries

- Our selector tool helps you to find the most relevant journal

- We provide round the clock customer support

- Convenient online submission

- Thorough peer review

- Inclusion in PubMed and all major indexing services

- Maximum visibility for your research

Submit your manuscript at www.biomedcentral.com/submit
C Biomed Central 